\title{
Temporalization of Experiencing: First-Hand Experience of the Nation in Mid-Nineteenth Century Finland
}

\author{
Heikki Kokko
}

\section{INTRODUCTION}

How and when did the nation become a relevant identity category for ordinary people? Giving a clear answer to this question is usually difficult because of the lack of historical source material. There is a shortage of autobiographic material such as diaries that could have documented this kind of change at the time when it happened. This concerns people from all social strata, but especially those from lower layers of society whose experience could be an indicator of a wider societal change. Due to the lacking empirical evidence, first-hand experience of the nation has been difficult to obtain. Therefore, the emergence of the experience of the

\footnotetext{
H. Kokko (四)

Tampere University, Tampere, Finland e-mail: heikki.kokko@tuni.fi

(C) The Author(s) 2021

V. Kivimäki et al. (eds.), Lived Nation as the History of Experiences and Emotions in Finland, 1800-2000, Palgrave Studies in the History of Experience, https://doi.org/10.1007/978-3-030-69882-9_5
} 
nation, whether it was a matter of modernization or not, has remained a controversial issue in nationalism studies. ${ }^{1}$

A case that could shed light on this phenomenon is that of mid-1800s Finland. The industrialization and formation of modern society began in Finland at a late stage, but once it started it transformed Finland from one of the most agrarian countries in Europe to a Nordic welfare state within a century. ${ }^{2}$ The comparatively late and exceptionally rapid societal changes that influenced the whole population after hundreds of years of relatively slow development, as well as the compactness of Finland as a society with a population of 1.6 million in 1850, make mid-1800s Finland a representative and controllable case for this analysis. Within two decades, 1850s-60s Finland witnessed large-scale social and economic reforms, a major population disaster in the form of a famine, and the rise of a nationwide public sphere. Significantly, a nationwide culture of readers' letters to newspapers developed during this first phase of modernization. Thousands of people wrote about their everyday experiences to the pages of the newspapers from the 1850s onwards. A characteristic of this culture was that the letters were often written in the name of local communities. In their local letters to the newspapers, hundreds of ordinary people documented their experiences of the societal transformation occurring in the mid-1800s. ${ }^{3}$

One of the writers of these letters was Johan Hänninen. He was born in 1842, the son of a crofter and the first in his family to disentangle himself from the agrarian self-sufficient community of the rural parish. During this process, he absorbed a modern form of nationalism, and was the first person of his family to do so. Because of Hänninen's writing activity, the changes in his experience of belonging are documented in his readers' letters. Later in his life, Hänninen became a wide-ranging grass-roots pioneer of the civic society, participating in social movements such as agricul-

\footnotetext{
${ }^{1}$ See, for example: Anthony D. Smith, The Nation in History: Historiographical Debates about Ethnicity and Nationalism (Hannover: UPNE, 2000).

${ }^{2}$ Pertti Haapala, "Modernisation of Finland 1800-2000," in Perspectives to Global Social Development, ed. by Mikko Perkiö (Tampere: Tampere University Press, 2009), 48-66; Pauli Kettunen, "The Conceptual History of the Welfare State in Finland," in The Changing Meanings of the Welfare State: Histories of a Key Concept in the Nordic Countries, ed. by Nils Edling (New York: Berghahn, 2019), 226-8.

${ }^{3}$ Heikki Kokko, "Suomenkielisen lehdistön paikalliskirjekulttuuria tallentava digitaalinen Translocalis-tietokanta," Ennen ja nyt: Historian tietosanomat 19:2 (2019a).
} 
tural meetings (1870s), the temperance movement (1880s), a co-operative organization (1890s), and a political party in the first parliamentary elections (1907). ${ }^{4}$

As an active participant in the nationwide culture of writing letters to the press in Finland, Hänninen could be seen as a representative case for Benedict Anderson's thesis regarding the emergence of the experience of the nation mainly as a product of the press. Anderson's thesis of "imagined community" is perhaps the most influential modernist theory concerning the origins and spread of nationalism. It is a constructionist approach that has been widely accepted beyond the borderlines of different disciplines, such as history, sociology, and anthropology since the beginning of the 1980s. ${ }^{5}$ Anderson's argument in his classic book is that the experience of the nation is the experience of belonging to an imagined community and goes beyond one's face-to-face interaction. For Anderson, the imagined community is a product of modernity, especially in regard to the development of modern printing technology. According to him, the newspaper in particular transformed the experience of time and space. This opened the way to imagining the nation as a community of people who spoke the same language. ${ }^{6}$ Anderson's approach is general; he concentrates on the wider structures that were preconditions to the experiential change that enables the experience of the nation. Johan Hänninen's case could add more to this picture by widening the approach to the individual level.

In this chapter, I approach nationalism as a form of the experience of belonging. ${ }^{7}$ I will test and develop further Anderson's thesis regarding "imagined communities" by analyzing the experiential change that an emerging experience of the nation required at the individual level. Using Hänninen as a case study, I will argue that the emergence of one's experience of the nation was based on a transformation in the structures of experiencing, in which modern linearly progressing temporality began to

\footnotetext{
${ }^{4}$ Heikki Kokko, Kuviteltu minuus: Ihmiskäsityksen murros suomenkielisen kansanosan kulttuurissa 1800-luvun puolivälissä (Tampere: Tampere University Press, 2016), 315-16.

${ }^{5}$ See John Breuilly, "Benedict Anderson's Imagined Communities: A Symposium," Nations and Nationalism 22:4 (2016), 625-59.

${ }^{6}$ Benedict Anderson, Imagined Communities: Reflections on the Origin and Spread of Nationalism, rev. ed. (London: Verso, 2006 [1983]), 22-36.

${ }^{7}$ By belonging I refer to an experience that includes the interaction between one's personal identity and a sense of membership of the community. See, for example, Eleanor Knott, "Nationalism and Belonging: Introduction," Nations and Nationalism 23:2 (2017).
} 
define the way people experienced. In order to discover the structural basis, I will analyze the form of Hänninen's experience of the nation and his form of belonging that preceded it. I will examine the content and personal significance of these two modes of belonging and contextualize them within the life history of Hänninen in mid-1800s Finland. Broadly, this will shed light on the character of nationalism at the time it emerged as a societal phenomenon.

\section{Research Material}

The significance of Hänninen's experience of the nation as a case is founded on the societal representativeness of the nationwide culture of local letters to newspapers. The Finnish Academy Centre of Excellence in the History of Experiences (HEX) has collected all the readers' letters written in the name of local communities and published in the Finnishlanguage press during the period $1850-1875,{ }^{8}$ from the fully digitalized newspaper collection of the National Library of Finland. ${ }^{9}$ The digital Translocalis database includes about 27,000 letters to newspapers which contain grass-roots experiences from the interface of modernity. ${ }^{10}$ This chapter contributes to the research field of the history of vernacular writing ${ }^{11}$ by using the systematically collected readers' letters as source material. The large-scale usage of the local letters to the newspapers as source material has not been possible prior to this.

The significant feature of the culture of writing letters to the press in mid-1800s Finland was the anonymity of the writers. The writers usually signed their letters only with initials or pseudonyms. This usually leads to difficulties in recognizing people like ordinary peasants and crofters. ${ }^{12}$ Johan Hänninen is a rare and special case among the writers from the lower stratum of society, because his identity and the features of his life history were possible to trace. This was possible because I managed to identify him through comparing his local letters that were written in the

\footnotetext{
${ }^{8}$ Kokko (2019a).

${ }^{9}$ Digital Collections of the National Library of Finland, http://digi.kansalliskirjasto.fi/, accessed 27 August 2020.

${ }^{10}$ See Translocalis Database, https://research.tuni.fi/hex/translocalis/, accessed 18 May 2021; Kokko (2019a).

${ }^{11}$ See Anna Kuismin \& M.J. Driscoll, eds, White Field, Black Seeds: Nordic Literacy Practices in the Long Nineteenth Century (Helsinki: SKS, 2013).

${ }^{12}$ Kokko (2019a).
} 
name of parishes to the church records of the parishes in which he had lived. ${ }^{13}$ With over 50 published letters found in the Translocalis database in 1868-1875, Hänninen is one of the most productive writers of this era. ${ }^{14}$ I have contextualized the experiences of Hänninen's letters by using biographical source material about his life. ${ }^{15}$

As a part of the culture of the letters to the press, the experiences Hänninen wrote about had societal representativeness compared to, for example, private diary entries. The conventions of the nationwide culture of local letters were socially constructed by the writers who sent their texts to the press. Furthermore, hundreds of writers and thousands of readers across the country cautiously controlled what the other authors wrote. The debates and comments on other authors' letters were a characteristic feature of this culture of letters to the press. As the debates were public and nationwide, the control by the peer group was societal in character. ${ }^{16}$

\section{Theoretical and Methodological Aprroach}

My theoretical framework as a researcher of historical experiences is an application of the sociology of knowledge promoted by Peter Berger and Thomas Luckmann, which I combine with Reinhart Koselleck's historical theory of experience and experiencing. ${ }^{17}$ Based on Berger and Luckmann, I see human experiencing as the construction of social reality. Experiencing is not an inner process individual in its essence. Rather, it is based on constant interaction between subjects. Both experiences and experiencinglike all elements of human reality-develop in a dialectic process between nature and the socially constructed world. In this dialectic process, the human organism itself is changing. ${ }^{18}$

${ }^{13}$ Kokko (2016), 457, 299-315.

${ }^{14}$ Translocalis Database.

${ }^{15}$ See Kokko (2016), 457, 299-315.

${ }^{16}$ Kokko (2019a); Heikki Kokko, "Kosminen kokemus: Hengellisen ja maallisen dualismi 1800-luvun puolivälin suomenkielisessä kansanomaisessa ajattelussa," in Eletty historia: Kokemus näkökulmana menneisyyteen, ed. by Johanna Annola, Ville Kivimäki \& Antti Malinen (Tampere: Vastapaino, 2019b), 12-16; see also Päiviö Tommila, "Yhdestä lehdestä sanomalehdistöksi 1809-1859," in Suomen lehdistön historia 1: Sanomalehdistön vaiheet vuoteen 1905, ed. by Päiviö Tommila et al. (Kuopio: Kustannuskiila, 1988), 77-266, here 200-4.

${ }^{17} \mathrm{I}$ am developing this theoretical framework for the history of experiences along with Dr. Minna Harjula.

${ }^{18}$ Peter Berger \& Thomas Luckmann, The Social Construction of Reality: A Treatise in the Sociology of Knowledge (London: Penguin, 1991 [1966]), 33-42, 201-4, 233. The recent 
I apply Koselleck's concept layer or sediment of experience approach along with Berger and Luckmann's thesis on the sedimentation of experiences as analytical tools for examining societal experiential change. According to Koselleck, experience is something that has already occurred but takes place today. It is the presence of the past within the present. For an individual, it is at the same time something that one can remember from the past and something that the individual had not been in touch with. This is because experiences usually convey elements of earlier generations that influence the individual's observation and thoughts unconsciously. As Koselleck has stated, experience based in the past is something where "many layers of earlier times are simultaneously present." This means that unlike the modern concept of history suggests, in the temporality of experience, time is not linear, progressing from a single time era to another. Rather, via layers of experience, past historical times are simultaneously present in the present. ${ }^{19}$

The emergence of layers of experiences could be explained by Berger and Luckmann's thesis on sedimentation. Experiences that have enough significance could become sedimented in one's mind. Other individuals in the same historical context may have the same kind of experiences. When these individuals interact with each other, their experiences become common experience. This common stock of knowledge may be objectivated in a sign system, such as language or institutional practices. The sign system detaches the experience from its original context and makes it anonymous. The sign system transmits experiences to people who have no connection to the original experience. As these people absorb the experience, they start to think or act in the same way as the original experiencers. The objectivated and anonymized experience can thus be transmitted to the next generations. At some point, however, the connection to the original experience will be lost. Hence, new generations can invent new meanings for the sediments of experience. Therefore, the layers or sediments of

research on neurosciences supports this premise of Berger's and Luckmann's social constructionism by emphasizing the plasticity of the human brain. The historical, cultural, and social factors formulate the human being also as a biological organism. Tuomas Tepora, "What, if Anything, Can the History of Emotions Learn from the Neurosciences?" Cultural History 9:1 (2020), 95-8; Rob Boddice, The History of Emotions (Manchester: Manchester University Press, 2018), 142-54.

${ }^{19}$ Reinhart Koselleck, Futures Past: On the Semantics of Historical Time, translated by Keith Tribe (New York: Columbia University Press, 2004), 259-63. 
experience not only outline how we confront individual observations, but also how we structure and thus construct the entire reality. ${ }^{20}$

Besides experience, the sense of belonging to the nation could be seen as an emotion. In my analysis, I see emotion as the sub-category of the experience. The emotion toward the nation is an experience of the nation. Following Sara Ahmed, I don't see the emotions, feelings or experiences as private matter flowing from the inward sphere of the human being. Rather, they are situated in the interaction between human beings and the objects of the world. Within this interaction, human beings categorize the world with classifications such as inside and outside of the human being. This is how, to put it in Ahmed's words, "feelings make 'the collective' appear as if it were a body in the first place." Experience of the nation is a characteristic example of this kind of feeling. ${ }^{21}$

Methodologically, I relate to the conceptual history, which I understand in the Koselleckian sense primarily as the analysis of human experiencing. New concepts emerge or the meaning of the concepts is transformed when the experiences behind them change. Written past experiences can be reconstructed by analyzing how concepts are used in historical sources and by contextualizing them using the methods of social-science history.

\section{Experience of the People}

Johan Hänninen wrote his first published readers' letters to the newspaper Kansan Lehti in the winter of 1868. The name of the newspaper could be translated into English as "People's Paper." It was a Finnish-language newspaper that publicly asked its readers to write letters that it could print in the newspaper. According to the editor of the Kansan Lehti, the paper wanted to provide an organ for the people of Finland. ${ }^{22}$ In his first letter, Hänninen used the concept of "kansa" (people) in expressing his belonging. In the first sentence of the letter, he wrote: "Because I too belong to the people, whose Newspaper You, the young Kansan Lebti, have devoted yourself to be, please let me salute you with the news from my parish." ${ }^{23}$

\footnotetext{
${ }^{20}$ See Berger \& Luckmann (1991), 85-9, 33-61.

${ }^{21}$ Sara Ahmed, "Collective Feelings. Or, the Impressions Left by Others," Theory, Culture o Society 21:2 (2004). See also Boddice (2018), 82-3.

${ }^{22}$ Wolmar Schildt, "Kunnioitetulle yleisölle," Kansan Lehti 4 January 1868.

${ }^{23}$ J. H-n. [Johan Hänninen], "Rautalammilta," Kansan Lebti 21 March 1868.
} 
The concept of "kansa" that Hänninen used dates to the sixteenth and seventeenth centuries. It frequently occurred in the old Finnish-language Bible and in old law books. ${ }^{24}$ It has its origins in the Finnish preposition "kanssa," which means "with." Therefore, to belong to the people in Finnish literally refers to "being with the fellow people." 25 The meanings of the Finnish concepts of people and nation are close to each other. "Kansakunta" (nation) that also becomes common in mid-1800s is a compound word formulated from the word "kansa" (people) and from the word "kunta," which refers to the unity or community of an entity. Besides "kansakunta," the word "kunta" is used in compound words such as "yhteiskunta" (society) and "kuningaskunta" (kingdom). In the 1860s the word "kunta" came to signify rural administrative districts that were earlier called parishes $($ pit $\ddot{a j} \ddot{a}){ }^{26}$

The word "Kansa" (people) was a central concept in the publicity of mid-1800s Finland. According to Ilkka Liikanen, it became politicized by the Finnish-speaking nationalistic elite during the 1860s and 1870s. At that time, the Finnish-speaking nationalistic elite used this word as a means of presenting the people as a separate entity that did not include the ruler. The nationalistic elite legitimized its own role by claiming to represent the will of the people (kansa). This was a way of challenging the distributing of power in the society. ${ }^{27}$

However, the "kansa" to which Hänninen expressed his belonging in 1868 did not include the kind of people that the nationalistic elite promoted. Hänninen did not use the concept of "kansa" to separate from the distinct entity. Instead, he emphasized that the "kansa," as well as all beings, are under the power of almighty God. According to Hänninen the Finnish people relied too much on themselves. This produced a disbelief in God, which caused people to fail to observe the Sabbath and spend it in acquiring worldly knowledge and enjoying different amusements. ${ }^{28}$ This could be seen as a critique of the national project of the elite that made efforts to put Finnish-speaking people on a pedestal.

\footnotetext{
${ }^{24}$ Ilkka Liikanen, “Kansa: Fennomanian kansa-käsite ja modernin politiikan kieli,” in Käsitteet liikkeessä: Suomen poliittisen kulttuurin küsitehistoria, ed. by Matti Hyvärinen et al. (Tampere: Vastapaino, 2003), 263-7.

${ }^{25}$ Henrik Stenius, "Kansalainen," in Hyvärinen et al. (2003), 312-14.

${ }^{26}$ See Pauli Kettunen, "Yhteiskunta," in Hyvärinen et al. (2003), 176-181.

${ }^{27}$ Liikanen (2003), 280-2.

${ }^{28}$ J. H-n. [Johan Hänninen], “Rautalammilta," Kansan Lehti 21 March 1868, 28 March 1868, and 11 May 1868.
} 
The actual topic of the letter was the famine, later called "The Great Hunger Years of 1866-8," the last year of which was being lived at the same time Hänninen wrote his text. For Hänninen the experienced hunger was unambiguously the revenge of God directed toward the people of Finland. ${ }^{29}$ According to Hänninen, all the common efforts of contemporary people to ease the famine's distress were completely useless. The only thing that could help the people of Finland were the Christian texts that the authorities had ordered to be read on the day of prayer. ${ }^{30}$ Hänninen emphasized that the relief of the disaster could happen via the grace of God alone and the only thing the members of the Finnish population could do about it was to strive for personal repentance and righteousness. ${ }^{31}$

Hänninen justified his thought by referring to the Old Testament of the Bible. He encouraged his audience to read the first chapter of the Book of Haggai to understand the real reasons behind the famine. According to the Book of Haggai, instead of rebuilding the temple of God, the people of Judah concentrated on building their own homes. This led to crop failure and famine as the punishment of God. ${ }^{32}$ Hänninen emphasized that the revenge of God was not caused by inefficiency or bad economic skills of the people of Judah. Instead, it was caused by their disbelief and self-reliance. ${ }^{33}$ Similarly, according to Hänninen, the main reason for the Finnish famine was not the laziness, ignorance, or dissipation of the people, although this was the usual explanation in the press. For Hänninen, the essential reason for the famine disaster was the sin of self-reliance. Referring to the efforts of the nationalistic elite to develop national progress and public enlightenment Hänninen wrote: "Surely, there is no longer any reason to encourage the [Finnish] people to rely on themselves, but on God; And this indeed is the intention of God with this punishment." ${ }^{34}$

The main strains of Hänninen's idea of comparing the Finnish people to biblical peoples could be traced to the interpretation of Lutheran

\footnotetext{
${ }^{29}$ J. H-n. [Johan Hänninen], "Rautalammilta," Kansan Lehti 28 March 1868.

${ }^{30}$ J. H-n. [Johan Hänninen], "Rautalammilta," Kansan Lehti 11 May 1868.

${ }^{31}$ J. H-n. [Johan Hänninen], "Rautalammilta," Kansan Lehti 21 March 1868, 28 March 1868, and 11 May 1868.

${ }^{32}$ J. H-n. [Johan Hänninen], "Rautalammilta," Kansan Lehti 28 March 1868.

${ }^{33}$ J. H-n. [Johan Hänninen], "Rautalammilta," Kansan Lehti 28 March 1868.

${ }^{34}$ J. H-n. [Johan Hänninen], "Rautalammilta," Kansan Lebti 21 March 1868, 28 March 1868, and 11 May 1868.
} 
doctrine in nineteenth-century Finland. The Lutheran church was a state church in Finland and its doctrine was taught to the entire population, except for the 2.3 percent minority of Orthodox Christians. ${ }^{35}$ The master narrative of Lutheranism was that, at the Creation, God created human beings like God, but, because of the Fall, those beings became mortal. Based on this master narrative, the interpretation of Lutheranism had two main principles in nineteenth-century Finland. Firstly, that human being had become inherently and thoroughly sinful due to the Fall. Secondly, that the human being could not reach salvation by his or her own actions but only through the grace of God. This caused a dualistic division between the spiritual and the earthly, the former being primary and the latter secondary. ${ }^{36}$ In his letter of 1868, Hänninen followed the strict interpretation that all earthly activity, such as human ambition for national development, did not have the Lord's blessing, because He ordained all. Therefore, Hänninen believed that the Christian texts that were read in the parishes for the day of prayer could provide the only possible relief, because, according to Lutheran doctrine, the power of the authorities stemmed from God. ${ }^{37}$

This kind of thought allowed no room for agency of the people as a community to tackle contemporary problems. Therefore, the people of Finland to which Hänninen believed he belonged, did not decide their own fate in the grip of the famine: they had no agency. The agency of the human being was limited to gaining salvation in order to go to heaven. Thus, the domain of individual efforts was limited to the sphere of spirituality, since the common efforts of human beings were considered earthly activity that originated from the Fall. ${ }^{38}$ The only thing that a human being could do on this earthly side was to have faith in God. In his letter of 1868, Hänninen expressed this dualistic division between the spiritual and the earthly tangibly by stating that even starvation to death was a victory for the truly Christian human being, if it was the will of God. ${ }^{39}$ This kind of thought was in contradiction to the then-current nationalistic ideology

\footnotetext{
${ }^{35}$ See Esko M. Laine \& Tuija Laine, "Kirkollinen kansanopetus," in Huoneentaulun maailma: Kasvatus ja koulutus Suomessa keskiajalta 1860-luvulle, ed. by Jussi Hanska \& Kirsi Vainio-Korhonen (Helsinki: SKS, 2010), 258-312.

${ }^{36}$ Kokko (2019b), 120-32.

${ }^{37}$ J. H-n. [Johan Hänninen], "Rautalammilta,” Kansan Lehti 11 May 1868.

${ }^{38}$ Kokko (2019b), 120-9.

${ }^{39}$ J. H-n. [Johan Hänninen], “Rautalammilta,” Kansan Lehti 11 May 1868.
} 
of the elite, whose ambition was for national development produced by a common effort of the people.

If Hänninen's belonging to the people is examined in light of Anderson's theory of imagined community, it can be seen that in many ways it did not resemble the nation as an imagined community. Hänninen's "kansa" seems not to have its peculiar past, present, and future based on the activity of its members. It did not resemble Anderson's nation as "the idea of sociological organism moving calendrically through homogenous, empty time," or more precisely as a "solid community moving steadily down (or up) history." 40 Rather, the "kansa" of Hänninen comes close to embodying the features that according to Anderson were typical of imagined communities prior to modern nationalism. Indeed, the straightforward paralleling of nineteenth-century Finnish people and the ancient biblical people of Judah seems to resemble a conception in which, according to Anderson, history was not seen "as an endless chain of cause and effect" and there were no "radical separations between past and present."41

However, the "kansa" of Hänninen seems to have a feature that Anderson recognizes as essential to modern nationalism. Anderson's thesis is that nationalism was based on a new kind of temporal simultaneity. According to Anderson, the nation as an imagined community was based on the experience of the horizontal temporal simultaneity of the present, which could be described with the concept of "meanwhile." ${ }^{2}$ This created confidence in the anonymous activity of one's contemporaries as a core of nationalism. ${ }^{43}$ Hänninen's letter shows that he experienced this kind of temporal simultaneity. He wrote his letter to his contemporaries whom he saw as forming the people of Finland, who were simultaneously suffering from famine in different parts of the country. This could be seen as confidence in the anonymous activity of his contemporaries. However, Hänninen had no confidence that the activity of the "kansa" would be supportive of the nation that had its human-made past, present, and future. His confidence was based on Lutheran doctrine that emphasized every individual's personal salvation, something that Hänninen believed could relieve the famine distress. The connection between his

\footnotetext{
${ }^{40}$ Anderson (2006), 26.

${ }^{41}$ Anderson (2006), 22-4, 36.

${ }^{42}$ Anderson (2006), 24-36.

${ }^{43}$ Anderson (2006), 26.
} 
contemporaries in the present was based on a belief in every individual's personal relationship to God.

As seen through Anderson's theory, Hänninen's experience of the people seems to be a kind of hybrid form of the experience of the nation and an earlier form of belonging to it. It was founded on temporal simultaneity at the present moment, but not on the linear temporality that goes from the past to the present and the future. It could be that Hänninen, who was under the influence of the press, had experienced horizontal temporal simultaneity as a sense of "meanwhile." However, in his mind it intermingled with the thesis of the Lutheran doctrine, in which the linear progressing temporality that structured human activity throughout history had no significant role. Therefore, the community of people had no independent agency throughout the course of history. It seems to be that Hänninen's experience of belonging to this "people," which had a biblical model, had a different structural emphasis than that of modern nationalism.

\section{EXPERIENCE OF THE NATION}

After the first readers' letters in the spring of 1868, Hänninen took a oneand-a-half-year break in writing. At the beginning of 1870 he started again. In the letters Hänninen wrote at that time, he no longer wrote about the Finnish inhabitants as a "people" (kansa) comparable to biblical peoples. Instead, the concepts of "nation" (kansakunta) and "fatherland" (isänmaa) appeared for the first time in his vocabulary. ${ }^{44}$

The nation of Hänninen more and more resembled Anderson's imagined community. Significantly, unlike his earlier conception of the people, the nation of Hänninen was structured by the linear temporality that was absent from his earlier conception of the people. The first sentence of the first letter in which Hänninen expressed his experience of the nation in 1870 was: "I see the common progress of my fatherland (isänmaa) as holy, dear and beloved." 45 This sentence is especially interesting, because it had a clear temporal structure of linear progressing time. The "common progress" could be seen to refer to the future of the nation, the "fatherland" referred to the past of the nation as the land of the ancestors, and the "holy, dear and beloved" to the emotions that the nation evoked in his mind in the present. This linear temporal structure linked to the nation

\footnotetext{
${ }^{44}$ J. H-n: [Johan Hänninen], “Kirje A. Jle Rilla," Kansan Lehti 26 February 1870.
}

${ }^{45}$ J. H-n: [Johan Hänninen], "Kirje A. Jle Rilla," Kansan Lebti 26 February 1870. 
also appeared in other Hänninen letters of the 1870s. Interestingly, in many of these texts he tried to the catch the abstractness of this structure, especially in metaphors related to family. In addition to using "father" to refer to the past of the nation, Hänninen frequently used "children" for the symbol of the future of the nation. ${ }^{46}$ In his letters of the $1870 \mathrm{~s}$, he occasionally signed them with the expression "your brother," and frequently addressed his fellow readers and writers as "brothers" and "sisters" (veikot and siskot). ${ }^{47}$ They were the representatives of the present in Hänninen's experience of the nation.

Besides Hänninen's experience of linear temporality, his experience of horizontal temporal simultaneity, the sense of "meanwhile" that, according to Anderson, is a distinctive feature of modern nationalism, was now different. In Hänninen's earlier experience of "people," the connection between contemporaries was established via God. As Anderson argues, in the experience of the nation the connection was founded on confidence in the anonymous activity of one's contemporaries. ${ }^{48}$ This was crystallized in one of Hänninen's letters, in which he explained what he meant by calling his fellow readers and writers brothers and sisters. Hänninen wrote that a brother was someone whom he did not recognize from his coat or face, but whom he recognized from the message that came from inside his or her heart. ${ }^{49}$ This could be seen as an example of confidence in the activity of distant contemporaries that were beyond the face-to-face interaction that Anderson sees as at the heart of the emerging experience of the nation. ${ }^{50}$ Hänninen began to trust in his imagination that there were numerous communities of people like himself, who worked for a nation that had its past, present, and future. Unlike with the earlier experience of the "people," the agency that defined the direction of the development of the community was in the grip of human beings.

It seems to be that this gave new significance to the present in Hänninen's thought. A characteristic feature of Hänninen's nation in the

\footnotetext{
${ }^{46}$ For example J. H-n: [Johan Hänninen], “Kirje Veikoille!” Kansan Lehti 19 March 1870; J. H-n: [Johan Hänninen], “Kirje A. Jle Rilla,” Kansan Lehti 16 May 1870.

${ }^{47}$ This was a common habit especially among the writers of Kansan Lehti. See Laura Stark, The Limits of Patriarchy: How female networks of pilfering and gossip sparked the first debates on rural gender rights in the nineteenth-century Finnish-language press (Helsinki: SKS, 2011). ${ }^{48}$ Anderson (2006), 24-36.

${ }^{49}$ J. H-n: [Johan Hänninen], “Kirje Helsingin Veikolle!” Kansan Lehti 2 May 1870. J. H-n: [Johan Hänninen], “Kirje Veikoille!” Kansan Lehti 14 May 1870.

${ }^{50}$ Anderson (2006), 24-36.
} 
1870s was the strong emotional tone that was directed toward the social issues of the current era. In his texts, Hänninen often associated social reforms and the nation with the human heart. In one of his letters, he hoped that civil servants for his nation would acquire "a pulsating national Finnish heart." ${ }^{51} \mathrm{He}$ called the city of Jyväskylä, where the training of elementary school teachers had started and where school activists had recently convened, "the pedagogical sweetheart of Finland," where people from across the country "rushed with heart pounding with joy" to meet fellow people. ${ }^{52}$ The first Finnish-language school in Helsinki was, for Hänninen, a "national institute" and "the Finnish people's institute of love." $" 53$

In fact, when Hänninen wrote about the nation, his focus was almost always on the current social conditions of Finland. The burning societal issue for him was the status of the Finnish language in comparison to Swedish. Therefore, Hänninen greeted with joy every piece of news which indicated any improvement in the status of Finnish. For example, Hänninen expressed his gratitude for the fact that the language used at the founding celebration of the first elementary school in Pieksämäki in 1872 was solely Finnish. ${ }^{54}$ The foundations of Finnish-language schools were close to his heart, in particular because he hoped for Finnish-language civil servants to serve the Finnish nation. ${ }^{55}$ Hänninen's nation went beyond current social barriers. In 1872, he thanked the founding celebration of the first elementary school in his home district for forgoing distinctions of rank at the event. According to Hänninen, the gentlemen treated the peasants as members of the people of the fatherland to which they themselves also belonged. ${ }^{56}$

The future of the nation played a significant role in Hänninen's thought because it intertwined with the present. Hänninen's approach to the future was connected with children and the youth. The social reforms that were conducted in the present, such as the establishment of

${ }^{51}$ J. H-n: [Johan Hänninen], "Pieksämäeltä,” Suomenlehti 2 September 1873.

${ }^{52}$ J. H-n: [Johan Hänninen], “Kirje A. -kk-lle Jämsässä,” Kansan Lehti 21 May 1870.

${ }^{53}$ J. H-n: [Johan Hänninen], "Pieksämäeltä," Suomenlehti 2 September 1873.

${ }^{54}$ J. H.: [Johan Hänninen], "Pieksämäeltä," Suomenlehti 19 November 1872.

${ }^{55}$ J. H-n: [Johan Hänninen], "Pieksämäeltä," Suomenlehti 2 September 1873.

${ }^{56}$ J. H.: [Johan Hänninen], "Pieksämäeltä,” Suomenlehti 19 November 1872. 
Finnish-language schools, were done for the next generations. ${ }^{57}$ Hänninen also supposed that confidence in the future was something he had in common with other readers and writers of the newspapers. Hänninen expressed this in one of his letters by assuming that he and his fellow writers shared high respect for the "nation and its flight of progress." ${ }^{8}$ It seems that, for Hänninen, children were the representatives of the future in the present. The activities in the present were carried out for them.

The past had less significance for Hänninen than the present and the future. Although Hänninen acknowledged the significance of the past for the nation, history seems to have been unimportant for his experience of the nation. In fact, Hänninen did not write at all about the history of the Finnish nation at the beginning of the 1870 s but only referred to the fact that there had been earlier generations living in Finland in the past. ${ }^{59}$ One obvious reason for this was that there was no existing historiography in the Finnish language that had put the Finnish nation on a pedestal. The first historical interpretation that provided ethnic roots for the Finnish-speaking population, and excluded the Swedish-speaking population from Finland, was completed by historian Georg Zacharias Forsman (later Yrjö Sakari Yrjö-Koskinen) in $1873 .{ }^{60}$ However, this was not a full picture. It seems to be that the distinctive feature of Hänninen's experience of nation was its emphasis on the present societal problems and the possibilities for the future in the present.

The structure of Hänninen's first-hand experience of the nation at the beginning of the 1870s seems to adapt Anderson's thesis about the experience of the "imagined community." As Anderson suggests, its core was in linear temporality and in the sense of temporal simultaneity. The case of Hänninen shows that the emerging of the nation as the imagined nation demanded a temporalization of the experience of belonging, which strengthened the role of human agency as the force that could change the world. This made Hänninen's early nationalism societal in its character.

${ }^{57}$ J. H-n: [Johan Hänninen], “Kirje Veikoille!” Kansan Lehti 19 March 1870; J. H-n: [Johan Hänninen], "Kirje A. Jle Rilla," Kansan Lehti 16 May 1870; J. H-n: [Johan Hänninen], “Kirje A. -kk-lle Jämsässä,” Kansan Lehti 21 April 1870.

${ }^{58}$ J. H-n: [Johan Hänninen], “Kirje Veikoille!” Kansan Lehti 19 March 1870.

${ }^{59}$ Translocalis Database, The letters of Hänninen 1868-75.

${ }^{60}$ Miikka Tervonen, "Historiankirjoitus ja myytti yhden kulttuurin Suomesta," in Kotiseutu ja kansakunta: miten suomalaista historiaa on rakennettu, ed. by Pirjo Markkola, Hanna Snellman \& Ann-Catrin Östman (Helsinki: SKS, 2014), 145-6. 
Nostalgia that is present in many later forms of nationalism was not characteristic of Hänninen's experience.

\section{The Process of the Formulation of the Experience OF THE NATION}

There is no question as to where Hänninen absorbed the ideological content of his experience of the nation and its temporal structure. As an active newspaper reader, he acquired that content from the Finnish-language press of the mid-1800s that was edited by the Finnish-language educated elite, who used the newspapers to promote their ideological agenda of a nationalism based on the idea of national progress. ${ }^{61}$ This was also an explanation that Hänninen offered himself in his memoirs, written in 1912. According to Hänninen, his national awakening began when he managed to get hold of and read a bound volume of the newspaper Aamurusko in his youth in the late-1850s. ${ }^{62}$ Aamurusko was edited by well-known representative of the Finnish nationalistic elite, Pietari Hannikainen. ${ }^{63}$ Furthermore, Hänninen could also find peer support for his experience of the nation from the culture of letters to newspapers that began to blossom in his youth and in which he participated, first as reader and later as a writer.

The question remains, what kind of process was the assimilation of the experience of the nation at the individual level? To understand this, we must take a closer look at Hänninen's life history. It is obvious that we cannot get inside his head. However, the information about his life course sheds light on the experiential change that first-hand experience of the nation demanded.

Hänninen was born into a Finnish-speaking family in the rural parish of Rautalampi in 1842 . His father was a crofter who also worked as a cobbler. ${ }^{64}$ In mid-1800s Finland, this meant a self-sufficient life in the local community in which people produced and consumed almost all the goods needed within their household. In these circumstances, crop failures, hunger, and infectious diseases were constant hazards. Death, especially of children, was always present. As chances for social mobility were limited,

\footnotetext{
${ }^{61}$ See for example Tommila (1988), 143-95.

${ }^{62}$ Harkki [Johan Hänninen], "Seitsemänkymmentä vuotta," Maakansa 14 May 1912.

${ }^{63}$ Tommila (1988), 187.

${ }^{64}$ Kokko (2016), 311.
} 
human beings usually lived their lives in the social position into which they had been born. ${ }^{65}$ This was due to the socio-economic situation of the period. Although the growing season in the north was short, 93 percent of the entire population lived in the countryside and 79 percent got their livelihood from agriculture. ${ }^{66}$ While 85 percent of the population of Finland was Finnish-speaking, Finnish was primarily the language of the common people, such as Hänninen, who lived in the numerous local rural communities. There were no state schools for Finnish-speakers and the Finnish-language literary culture was still in its infancy. ${ }^{67}$ Swedish-speakers formed 14 percent of the population. ${ }^{68}$ Swedish was the language of the central administration, the educated, and the Swedish-speaking common people. The Swedish language was difficult to learn for native Finnishspeakers, because it was linguistically distant and unrelated to Finnish. Lutheranism was the only socialization system provided by the authorities for Finnish-speaking people like Hänninen. He, just like everyone else, was required to go through confirmation classes at the age of about 15 to prove that he could read the Lutheran texts and understand the Lutheran doctrine. ${ }^{69}$

In his youth, Hänninen succeeded in achieving the ability to write. Because of the Lutheran emphasis on the personal reading of religious texts, some sort of ability to read was quite common in the countryside of Finland, but the ability to write was rare. The first official statistics (1880) show that under 13 percent of the whole population over ten years of age could write. ${ }^{70}$ This means that only a few percent of the Finnish-speaking adult population could write in the mid-1800s. Hänninen himself learned the ability to write in his youth through spontaneous efforts. According to his autobiographical article, this happened after he began to persistently commit to paper the songs that his father sang. ${ }^{71}$

The achieved literacy enabled Hänninen to get into the Finnishlanguage public sphere, which underwent the first upswing in his youth at the end of the 1850s. ${ }^{72}$ His literacy also made it possible in 1860 for

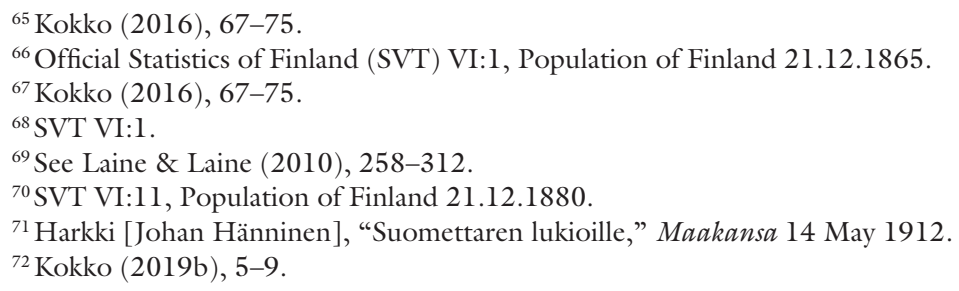


Hänninen to get into a two-year farming school at the age of 18. The farming schools, established at the end of the 1850s, were the first educational institutions that operated in the Finnish language. They educated land stewards and milkmaids to develop Finnish agriculture. ${ }^{73}$ For Hänninen, the farming school made it possible to develop as a reader and writer, because besides agricultural education, there was teaching in theoretical subjects as well. ${ }^{74}$ Hänninen undoubtedly familiarized himself with the ideas about the nation that he had read in the press available at the farming school. The school was led by Antti Manninen who was a selfeducated representative of the nationalism promoted by the educated elite. Furthermore, Manninen was one of the most productive contributors to the Finnish-language press in the 1850s and 1860s. ${ }^{75}$

After completing the farming school, Hänninen returned to his home district of Rautalampi and ended up working as an ordinary farmhand for years. However, the accelerating societal change in 1860s Finland increased the value of his literacy skills. Municipal reform in 1865 transferred local power from the Lutheran church to local landowners. As the reform had to be put into practice at the local level, this increased the social status of the people who had gained full literacy. This helped crofter's son and farm worker Hänninen to get a position of trust in the local government even though he did not have the right to vote. In 1867 Hänninen was chosen to be a deputy member of the local board for his home municipality even though he was not a landowner. At the same time, his status also improved in another way. In 1866, Hänninen got married to maid Karoliina Manninen and in 1867 they had their first child. ${ }^{76}$ As a married man with a family, Hänninen became a full member of the agrarian community.

As previously mentioned, in 1866-8 the population of Finland suffered "The Great Hunger Years," the last major famine in Europe along with the subsequent Swedish famine of 1867-9. During those years, about ten percent of the entire population of Finland died. The disaster touched almost everyone in Finland. Even though not all localities suffered from hunger, contagious diseases spread as crowds of beggars moved across the

\footnotetext{
${ }^{73}$ Arvo M. Soininen, Vanha maataloutemme: Maatalous ja maatalousväestö Suomessa perinnäisen maatalouden loppukaudella 1720-luvulta 1870-luvulle (Helsinki: SHS, 1975), 345-7.

74 “Kertomus Leväsen Maaviljelyskoulusta," Tapio 27 July 1861.

${ }^{75}$ See Kokko (2016), 140-56.

${ }^{76}$ Kokko (2016), 312-14.
} 
country. ${ }^{77}$ In 1868, during the third year of the disaster, at the age of 25 , Hänninen started his almost lifelong career as a newspaper letter writer, reflecting on his everyday experiences. His letters show that Hänninen experienced the famine's distress personally. In one of his letters from 1868 Hänninen described how he had eaten eight different substitutes for flour during the famine. ${ }^{78}$ Furthermore, his father died of a contagious disease during the first year of the famine in $1866 .^{79}$

The famine was undoubtedly a turning point in Hänninen's life. It seems that during it his spirituality increased in significance. Both his letters and the church records of his home parish indicate that during the famine his Lutheran faith deepened as he began to receive Communion regularly following a hiatus of several years. ${ }^{80}$ After the famine abated, Hänninen's religious thinking showed a change. In the 1870s he began to publicly promote the doctrine of the evangelical revival movement, and especially the branch that drew inspiration from the teachings of the Swedish preacher Carl Olof Rosenius. The teachings of Rosenius were popular, especially among the early newspaper writers of mid-1800s Finland, because the doctrine of Rosenius created a space within Lutheranism for the idea of earthly progress. ${ }^{81}$

Besides the experience of distress and a deepened Christianity, the "Great hunger years" opened a new opportunity for Hänninen. When crowds of beggars wandered across the country, some parishes began to establish temporary workhouses for them. In the parish of Mikkeli, this developed into a more permanent solution. In the spring of 1868, the parish established one of the first poor houses in Finland and Hänninen was hired as its first supervisor. ${ }^{82}$ This meant social climbing for the son of a crofter like Hänninen. It also meant disentanglement from his agrarian childhood region, where he had spent the first 26 years of his life. In 1870 , poor house supervisor Hänninen wrote letters in which he expressed his experience of the nation for the first time. In the 1870s, Hänninen

\footnotetext{
${ }^{77}$ Miikka Voutilainen, Poverty, Inequality and the Finnish 1860s Famine (Jyväskylä: University of Jyväskylä, 2016), 15-18.

78 "Rautalammilta," Tapio 25 May 1868.

${ }^{79}$ National Archives of Finland (NAF), Rautalampi rippikirja 1862-1871, p. 1201-2.

${ }^{80} \mathrm{NAF}$, Rautalampi rippikirja 1862-1871, p. 1201-2.

${ }^{81}$ Kokko (2016), 381-6.

${ }^{82}$ Kaarlo Wirilander, "Kun ensimmäinen maalaiskunta sai vaivaistalon vuonna 1868," Huoltaja 56:24 (1968), 838-43.
} 
became one of the most productive activists contributing to the culture of local letters. ${ }^{83}$

Hänninen's course in life suggests that the construction of one's experience of the nation and its temporal structure was not a sudden conversion but a long-term process. He received his first connection to nationalism via the press at the end of the 1850s but expressed an experience of the nation that could be identified as an imagined community for the first time in the 1870s. The culmination of this process seems to have been the disentanglement of Hänninen from his childhood world. Hänninen expressed an experience of the nation for the first time after he broke away from the social world of his home district and its interpretation of Lutheran doctrine. The experience of the nation began to blossom after he, as a married man, became a full member of the adult community, and after his social rise that disengaged him from the old agrarian self-sufficient mode of life. The broader societal context of the resurfacing of his experience of the nation was the economic boom that followed the famine in 1870s Finland. It seems that the progressive spirit of the time helped Hänninen trust in the new kind of experience of belonging that was based on the idea of linear earthly progress.

Hänninen's case indicates that the nation was not only an idea that was spread by the elites and learned by the ordinary people. It demanded profound experiential change for an individual like Hänninen, who lived the nation as a first-hand experience. The core of this transformation lay in absorbing the idea of linear temporality that led to conceiving of human agency as the master of all development.

\section{Two Societal Sediments of Experience}

Why were the experiences of Hänninen so different in 1868, when he expressed his belonging to the Finnish people (kansa), and later in the 1870s when his experience of the nation (kansakunta) emerged? To answer this question, Hänninen's experiential change needs to be analyzed from a societal perspective. Following Koselleck's and Berger and Luckmann's thought, Hänninen's conceptions of the nation and "people" and their temporal structures could be seen as the two different layers of experience that had sedimented in his mind during the course of his life. Instead of seeing these layers as the stages of development in Hänninen's

\footnotetext{
${ }^{83}$ Translocalis Database.
} 
thinking or in his personal identity, they could be seen as two different societally shared experiences of belonging that were both simultaneously present in the society and in Hänninen's conscious and unconscious thought. $^{84}$

Firstly, the earlier experience of the "people" was the societal layer of the experience of belonging that resurfaced in Hänninen's mind during the nationwide famine in 1866-8. It was based on his childhood primary socialization that was conducted by his significant others, mainly the members of his family. ${ }^{85}$ The theoretical basis of this socialization system was the Lutheran doctrine that was controlled by the state and its authorities via confirmation classes. This sediment, based on illiterate and selfsufficient agrarian life, resurfaced in the mind of Hänninen in the spring of 1868 when the famine was at its worst due to the grain crops failing for two to three years in a row. ${ }^{86}$ In these desperate circumstances, 25 -yearold Hänninen put his faith in the Lutheran doctrine that he had absorbed in his childhood. Ultimately, it promised a better life in heaven.

Secondly, the experience of the nation that Hänninen expressed later in the 1870s was based on the societal layer of experience, which began to be constructed when Hänninen succeeded in achieving literacy. This helped him to get included in the rising sphere of the Finnish-language press and enabled his social rise and disentanglement from his local environment. Breaking into the sphere of publicity made it possible for Hänninen to absorb the idea of the nation. As Anderson has suggested, the newspaper as a means drew his attention to linear progressive temporality and to the new kind of horizontal temporal simultaneity. ${ }^{87}$ Indeed, a hint of this "meanwhileness" had already become visible in Hänninen's earlier experience of the "people," when he addressed his fellow contemporaries as a God-ordained people living in the present.

The religious change in Hänninen created space for his new experience of the nation. At first glance, some could say that he simply began to think differently and in a more secular way. However, Hänninen's religious change indicates that absorbing the experience of the nation was not a matter of secularization. Preferably, it was about the reformulation of the Lutheran doctrine in a sense that enabled the experience of the nation.

\footnotetext{
${ }^{84}$ See Berger \& Luckmann (1991), 85-9.

${ }^{85}$ See Berger \& Luckmann (1991), 149-57.

${ }^{86}$ Voutilainen (2016), 15-18.

${ }^{87}$ Anderson (2006), 24-36.
} 
The doctrine of Carl Olof Rosenius that Hänninen supported emphasized the certainty of salvation if a human being experienced rebirth during his or her earthly life. Such rebirth meant that original sin could be expunged during one's earthly life. This reorganized the Lutheran dualism of the earthly and the spiritual and opened the domain of the earthly to a fresh idea of human progress, such as the nation. ${ }^{88}$ The change in Hänninen's religious thought made his experience of the nation based on a linear time theoretically possible.

The course of Hänninen's life points to the conclusion that at the end of the 1860s two societal layers of experience of belonging, the layer of the "people" and the layer of the nation, coexisted and interacted in his consciousness. This can be seen from a letter Hänninen wrote during the famine. In this text, he emphasized that under the circumstances of the famine there was no reason to encourage the Finnish people to rely on themselves. ${ }^{89}$ This was exactly opposite to what the nationalistic elite had promoted in the newspapers before and during the famine. Thus, this could be seen as resistance to the national discourse of the elite, while the vision of national progress had proved to be empty in the circumstances of famine distress. In the extreme conditions imposed by the famine, the layer of the nation stood aside, while the layer of the "people," to which he had been socialized in his childhood, resurfaced. Furthermore, the interaction between these two layers also continued later in Hänninen's life. The analysis of the relationship between the earthly and the spiritual remained a frequent theme in his writings during the following decades. ${ }^{90}$

Hänninen was a person who stood at the interface of the experience of the nation and the earlier form of belonging to it. By following Koselleck, it could be stated that the layer of the "people" was something in which past "experiences" of the past generations were present. ${ }^{91}$ In contrast, the layer of the experience of the nation was a first-hand experience that had no existing models in Hänninen's agrarian life. This could be seen as one reason why Hänninen's experience of the nation was based on the present and the future. From Hänninen's point of view, the nation as a first-hand experience had no past in his life history. Its emphasis was on improvement of current social conditions carried out on behalf of the next generations of the nation.

\footnotetext{
${ }^{88}$ Kokko (2016), 381-6.

${ }^{89}$ J. H-n. [Johan Hänninen], "Rautalammilta," Kansan Lehti 28 March 1868.

${ }^{90}$ See, for example, J. H-n. [Johan Hänninen], "Eräs epäkohta nuorison sivistyksessä," Savonlinna 22 April 1886.

${ }^{91}$ Koselleck (2004), 259-63.
} 
Indeed, Hänninen's experience of the nation follows the large-scale experiential transition that Koselleck has pointed to. Hänninen's emphasis on the present and future could be seen as the emerging of a modern horizon of expectations. According to Koselleck's thought, in the selfsufficient agrarian world, the experiences of the past and the expectations for the future interwove in such a way that temporality itself was not an essential category for experiencing reality. However, the large-scale changes seen in the eighteenth and nineteenth-century modernization process caused the horizon of expectations to move from the hereafter to earthly life. The Christian doctrine of completeness attained only in the hereafter was applied to a new idea of improvement on earth. This made it possible to convert the uncertainty stemming from the coming of the apocalypse to facing the hazards of an open future. This transformation was structured temporally together with the idea of progress. ${ }^{92}$ The broad context of the Hänninen case lies within this large-scale experiential transformation of experiencing itself.

Against this background, the emergence of Hänninen's experience of the nation can be seen as societal process, in which the categorizations of linear progressing time began to define Hänninen's experiencing process itself. The broader context of Hänninen's change to the form of belonging was the modernization process that reached the distant district of Rautalampi on the edge of Europe in the mid-nineteenth century. It captivated Hänninen and disentangled him from roots based on the selfsufficient agrarian life of past generations. For Hänninen himself this caused the experiential change that was a slowly progressing process with flashbacks to the old self-sufficient agrarian life. Hänninen was a man who lived at the interface between the premodern and the modern.

\section{Conclusion}

As Benedict Anderson has suggested in his thesis of "imagined communities," the case of Johan Hänninen indicates that first-hand experience of the nation was based on the conception of linear progressing time and on the new kind of experience of the significance of the present moment as something that went beyond face-to-face communication. This made confidence in the activity of fellow contemporaries the core of the experience of the nation.

${ }^{92}$ Koselleck (2004), 263-5. 
The case of Johan Hänninen opens a more nuanced perspective on Anderson's interpretation of the meaning of temporality in the emergence of the experience of the nation. Firstly, instead of characterizing the process as a transformation from simultaneity-along-time to the temporal horizontal simultaneity, this case study indicates that first-hand experience of the nation emerged when the temporality began to define the experiencing process itself. The case of Johan Hänninen indicates that first-hand experience of the nation was based on absorbing linear progressive temporality as the foundation of one's experiencing process itself. It led to a new conception of human agency and abilities. The human being now appeared as the master of earthly development, the manifestation of which was the nation.

Secondly, the Hänninen case points out that first-hand experience of the nation was based on the significance of the present moment and was legitimized by the expected future. Neither history nor nostalgia legitimized Hänninen's nation as occurs in many forms of later nationalism. Therefore, the Hänninen case highlights the societal character of early grass roots nationalism. In Hänninen's case, nationalism as an ideology was directed toward the current societal circumstances and legitimized by the expectations of a better future.

Thirdly, Hänninen's experiential change indicates that absorbing the experience of the nation was not a straightforward development or a sudden conversion. Instead, it was a slowly constructing process, in which the old societal layer of experience of belonging overlapped with a new kind of temporalized experience of the nation. These sediments of experience resurfaced in Hänninen's mind in different societal situations. Thus, the experience of the nation was the product of a changing society. This can be seen from Hänninen's life history that changed its course along with societal transformation, and from his experience of the nation which emphasized the significance of the present and the future, not of the past. Furthermore, Hänninen's case shows that absorbing of the experience of the nation was not an act of secularization in the sense that nationalism replaced religion. Instead, it was about the reformulation of religion in a manner that enabled the experience of the nation as an imagined community.

The case of Hänninen indicates that the press played a significant role in the emergence of the experience of the nation among ordinary people, as Anderson has previously pointed out. ${ }^{93}$ The press had a crucial role in

${ }^{93}$ Anderson (2006), 24-36. 
the circulation of information regarding the nation and a new kind of linear temporal structure of experiencing. However, the case of Hänninen also indicates that this mediatization must be seen as part of the multidimensional process of modernization that included simultaneously, for example, the spreading of literacy, the emerging of the division of labor, and the emerging of the modern state and citizenship therein.

Hänninen's case suggests that seeing nationalism as a straightforward top-down phenomenon, where the educated elite constructed the nation, is a delusion. The idea of the nation was the creation of the national elite, but the transformation that the breakthrough of it required was the result of changes in social reality that were driven by a modernization process that went beyond national borders. The temporalization of experiencing was too complex a process to be uniquely administered by any single group of the society.

Open Access This chapter is licensed under the terms of the Creative Commons Attribution 4.0 International License (http://creativecommons.org/licenses/ by $/ 4.0 /$ ), which permits use, sharing, adaptation, distribution and reproduction in any medium or format, as long as you give appropriate credit to the original author(s) and the source, provide a link to the Creative Commons licence and indicate if changes were made.

The images or other third party material in this chapter are included in the chapter's Creative Commons licence, unless indicated otherwise in a credit line to the material. If material is not included in the chapter's Creative Commons licence and your intended use is not permitted by statutory regulation or exceeds the permitted use, you will need to obtain permission directly from the copyright holder.

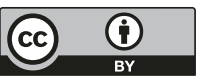

